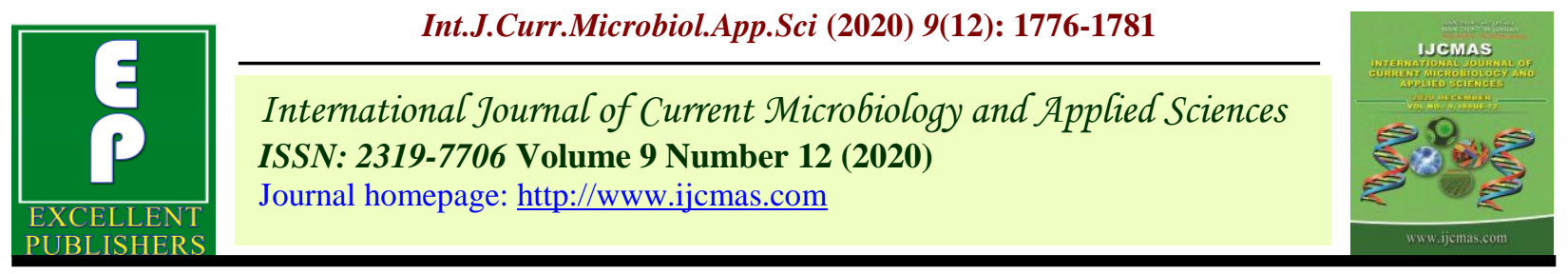

Original Research Article

https://doi.org/10.20546/ijcmas.2020.912.210

\title{
Effect of Pre Harvest Treatment of Gibberellic Acid and Calcium Chloride on Bunch Weight of Banana (Musa spp.) cv. Grand Naine
}

\author{
Lipsa Prit Bhusan $^{1 *}$, D.K. Dash ${ }^{1}$ and A.K. Das ${ }^{2}$ \\ ${ }^{1}$ Department of Fruit Science and Horticulture Technology, ${ }^{2}$ Department of Vegetable \\ Science, College of Agriculture, OUAT, Bhubaneswar, India \\ *Corresponding author
}

\begin{tabular}{|c|}
\hline Keywords \\
\hline $\begin{array}{l}\text { Banana, Bunch } \\
\text { weight, Yield, } \\
\text { Economics }\end{array}$ \\
\hline Article Info \\
\hline $\begin{array}{l}\text { Accepted: } \\
14 \text { November } 2020 \\
\text { Available Online: } \\
10 \text { December } 2020\end{array}$ \\
\hline
\end{tabular}

\section{A B S T R A C T}

The present study was undertaken at Horticulture Research Station, Department of Fruit Science and Horticulture Technology, College of Agriculture, OUAT, BBSR during 2015-16 and 2016-17 to envisage "Effect of pre harvest treatment of gibberellic acid and calcium chloride on bunch weight of Banana (Musa spp.) cv. Grand Naine". In this experiment fruits were subjected to ten treatments with different concentration of $\mathrm{GA}_{3}$, $\mathrm{CaCl}_{2}$, their combination, control (with water) and replicated thrice, after male bud removal chemicals were applied to the bunch by spraying. In this experiment maximum bunch weight $25.7 \mathrm{~kg}(2015-16), 23.9 \mathrm{~kg}$ (2016-17), yield 51.42t/ha (2015-16), 45.78t/ha (2016-17), with maximum benefit cost ratio $1.99,2.21$ respectively in plant crop and ratoon crop, was recorded in $\mathrm{GA}_{3} @ 150$ ppm and was found significantly superior.

\section{Introduction}

Banana is a monocarpic, monocotyledon, herbaceous plant and easily available with low cost having multipurpose use accompanied with essential vitamins and minerals. The earliest reference of banana (Musa spp) was found in the Hindu classicRamayana. Banana (Musa paradisiacal L.) belongs to the family Musaceae in the order Zingiberales is one of the most important fruit crops in the world (Samson, 1980) as it is available throughout the year, relatively inexpensive and is within the reach of all classes of buyers (Saravanan et al., 2012). It is a crop of subsistence being cultivated from prehistoric time in India with great socioeconomic significance and is grown in all tropical regions. It provides well balanced diet to millions of people around the globe and also contributes to livelihood through crop production, processing (Singh, 2002) and thus, plays a key role in the economy of many developing countries. The edible bananas are indigenous to warm and humid parts of Asia, which probably have their centre of origin. It 
cultivated over 130 countries in the tropical and subtropical regions. India ranks $2^{\text {nd }}$ in terms of area $(880.0 \mathrm{THa})$, first in production (30008.0Tton) and productivity is 34.1 ton/ha. In the state of Odisha area under banana is (24.73Tha) with annual production of (467.73Tton) (NHB 2015). Banana is considered as the Apple of paradise and the fruits are used for offering to Hindu Deities. From the nutritional point of view, banana is a richest source of carbohydrate and has a calorific value ranging from 67 to 137 calories per $100 \mathrm{~g}$ and is closely comparable with potatoes but digested more easily. It is relatively cheap. Out of large number of varieties grown in India, Basari was the most popular variety among growers and consumers. But with the introduction of high yielding variety Grand Naine, the area of Basari shriveled to a greater extend. Grand Naine is most popular in Gujarat and Maharashtra for domestic market and export. Consequently, a new thrust is emerging for higher yield, better fruit quality and longer shelf life with lesser susceptibility to pests and diseases. Therefore to improve the productivity, extending the area of high yielding banana varieties like Grand Naine, Robusta and Dwarf Cavendish are important. Grand Naine is the most accepted international variety and is gaining popularity in the state including its northern part also. With this background, the present investigation was carried out on "Effect of pre harvest treatment of gibberellic acid and calcium chloride on fruit weight of Banana (Musa spp.) cv. Grand Naine".

\section{Materials and Methods}

The present was carried out during 2015-16 and 2016-17 i.e. the plant crop followed by its ratoon crop in the Horticulture Research Station, Department of Fruit Science and Horticulture Technology, College of Agriculture, OUAT, Bhubaneswar. The experiment was conducted in RBD design with 10 different treatments each replicated thrice. Tissue culture plantlets of Grand Naine banana of 1 to 2 month age were collected for the experiment and were planted in pits. Plantlets of Banana (Musa spp., AAA group) cv. Grand Naine planted on December 2, 2015. Planting was done in the early morning to limit stress and allowed sufficient time for adaptation. During initial days of establishment, crop was daily irrigated. All cultural practices like manuring, irrigation, management of side suckers, removal of dried and diseased leaves, denavelling, propping of plants were done. After male bud removal, on selected plants spraying was done to the bunches. The treatment details are $\mathrm{T}_{1}: 2 \%$ $\mathrm{CaCl}_{2}, \mathrm{~T}_{2}: 3 \% \mathrm{CaCl}_{2}, \mathrm{~T}_{3}: 4 \% \mathrm{CaCl}_{2}, \mathrm{~T}_{4}: 50$ ppm $\mathrm{GA}_{3}, \mathrm{~T}_{5} ; 100$ ppm $\mathrm{GA}_{3}, \mathrm{~T}_{6}: 150 \mathrm{ppm}$ $\mathrm{GA}_{3}, \mathrm{~T}_{7}: 50 \mathrm{ppm} \mathrm{GA}_{3}+2 \% \mathrm{CaCl}_{2}, \mathrm{~T}_{8}: 100$ ppm $\mathrm{GA}_{3}+3 \% \mathrm{CaCl}_{2}, \mathrm{~T}_{9}: 150 \mathrm{ppm} \mathrm{GA}_{3}+4 \%$ $\mathrm{CaCl}_{2}, \mathrm{~T}_{10}$ : Control (with water application only). After attainment of maturity, bunches were harvested. After harvesting bunch length, bunch girth, bunch weight, number of hands, number of fingers per hand, finger length, finger girth were recorded and economics was calculated.

\section{Results and Discussion}

The bunch length, girth, weight and number of hands/ bunch of banana cv. Grand Naine in both the years were recorded after harvest and statistically analyzed. It is observed that there was no significant difference recorded in both the years when we consider about bunch length and number of hands per bunch. It shows that in $1^{\text {st }}$ year maximum girth of bunch was recorded in $\mathrm{T}_{6}(110.5 \mathrm{~cm})$ followed by $\mathrm{T}_{5}(107.6 \mathrm{~cm})$ and $\mathrm{T}_{4}(105.9 \mathrm{~cm})$. There was no statistical difference recorded between $\mathrm{T}_{6}$, $\mathrm{T}_{5}$ and $\mathrm{T}_{4}$. Bunch girth of minimum $96.7 \mathrm{~cm}$ was recorded in $T_{7}$ followed by $T_{10}(97.9 \mathrm{~cm})$, $\mathrm{T}_{8}(98.1 \mathrm{~cm})$ and $\mathrm{T}_{9}(98.5 \mathrm{~cm}) . \mathrm{T}_{7}, \mathrm{~T}_{10}, \mathrm{~T}_{8}, \mathrm{~T}_{9}$ were found statistically at par. Whereas in $2^{\text {nd }}$ 
year also maximum bunch girth was recorded in $\mathrm{T}_{6}(110.1 \mathrm{~cm})$ followed by $\mathrm{T}_{5}$ and $\mathrm{T}_{4}$ with $108.7 \mathrm{~cm}$ and $107.6 \mathrm{~cm}$ respectively. Treatment $\mathrm{T}_{6}, \mathrm{~T}_{5}, \mathrm{~T}_{4}$ and $\mathrm{T}_{2}$ were found statistically at par and minimum bunch girth was recorded in $\mathrm{T}_{10}$ in ratoon crop (2016-17). There was no significant difference recorded between $T_{10}$, $\mathrm{T}_{7}, \mathrm{~T}_{8}$ and $\mathrm{T}_{9}$. It is observed that maximum bunch weight was recorded in $\mathrm{T}_{6}(25.7 \mathrm{Kg}$, $23.9 \mathrm{Kg}$ ) in two years respectively followed by $\mathrm{T}_{5}$ and $\mathrm{T}_{3}$, where as minimum $22.4 \mathrm{~kg}$ (201516), $19.2 \mathrm{~kg}$ (2016-17) was recorded in $\mathrm{T}_{10}$, followed by $T_{7}, T_{8}$ and $T_{9}$. There was no significant difference recorded between $\left(T_{6}\right.$, $\left.\mathrm{T}_{3}, \mathrm{~T}_{5} \& \mathrm{~T}_{2}\right)$ and also between $\left(\mathrm{T}_{10}, \mathrm{~T}_{7}, \mathrm{~T}_{8}\right.$ $\& \mathrm{~T}_{9}$ ) during 2015-16 and in ratoon crop (2016-17) there was no significant difference recorded between $\mathrm{T}_{7}, \mathrm{~T}_{10}, \mathrm{~T}_{8}, \mathrm{~T}_{9}, \mathrm{~T}_{1}$ and $\mathrm{T}_{4}$. There was no significant difference recorded between all the treatments in both years when we consider number of hands/ bunch. However number of hands/ bunch varies from 8.45 to 9.23 in $2015-16$ and 8.10 to 9.91 in 2016-17.

As after initiation/germination there are 3 physiological stages i.e. growth, maturation and senescence. Growth and maturation are developmental phase. Growth includes cell division and cell expansion which accounts for final size of produce (Wills et al., 1981).

Due to pre harvest treatment as treatments were carried out in field and spraying to bunches were carried out during their developmental stage, it gets sufficient time to be absorbed by the fruits and superiority over control was observed. $\mathrm{GA}_{3}$ @ 150 ppm showed it superiority over others followed by $\mathrm{GA}_{3} @ 100$ ppm but when they applied in combination with $\mathrm{CaCl}_{2}$ there was no superiority recorded and it might be due to incompatibility of $\mathrm{GA}_{3}$ and $\mathrm{CaCl}_{2} \cdot \mathrm{GA}_{3}$ accelerate cell division and cell expansion hence fruit weight increases (Table 1).
Number of fingers/hand, finger length and finger girth of banana

Data pertaining to number of fingers/hand, finger length and finger girth of banana cv. Grand naine in 2 years are presented in table 2. There was no significant difference recorded when we consider about number of fingers/hand in both years. Number of fingers/ hand varies from $(16.08-16.96)$ in plant crop and $(15.61-16.59)$ in ratoon crop.

It is observed from Table 2 that finger length varies from $(22.32 \mathrm{~cm}-25.87 \mathrm{~cm})$ in $2015-16$ and $(22.33 \mathrm{~cm}-25.83 \mathrm{~cm})$ in $2016-17$. In $1^{\text {st }}$ year maximum finger length was observed in $\mathrm{T}_{6}(25.87 \mathrm{~cm})$ followed by $\mathrm{T}_{5}(24.70 \mathrm{~cm})$ and there was no significant difference recorded in between $\mathrm{T}_{6}, \mathrm{~T}_{5}$ and $\mathrm{T}_{4}$. Minimum finger length of $22.32 \mathrm{~cm}$ was observed in $T_{10}$ in $1^{\text {st }}$ year and $\mathrm{T}_{10}$ was found at par with $\mathrm{T}_{7}, \mathrm{~T}_{8}, \mathrm{~T}_{9}$, $\mathrm{T}_{2}$ and $\mathrm{T}_{1}$. Similar trend is also recorded in $2^{\text {nd }}$ year as maximum finger length $24.83 \mathrm{~cm}$ was recorded in $\mathrm{T}_{6}$ followed by $\mathrm{T}_{5}(23.78 \mathrm{~cm}), \mathrm{T}_{6}$, $\mathrm{T}_{5}, \mathrm{~T}_{4}$ and $\mathrm{T}_{3}$ were found statistically at par. Minimum $21.33 \mathrm{~cm}$ finger length was recorded in $\mathrm{T}_{10}$ and $\mathrm{T}_{7}$ in ratoon crop.

In 2015-16 maximum finger girth was observed in $\mathrm{T}_{6}(15.10 \mathrm{~cm})$ followed by $\mathrm{T}_{5}$ $(14.86 \mathrm{~cm}), \mathrm{T}_{4}(14.13 \mathrm{~cm})$. There was no statistical difference recorded in between $\mathrm{T}_{6}$, $\mathrm{T}_{5}$ and $\mathrm{T}_{4}$. Minimum finger girth of $13.17 \mathrm{~cm}$ was recorded in $\mathrm{T}_{10}$ followed by $13.27 \mathrm{~cm}$, $13.48 \mathrm{~cm}, \quad 13.52 \mathrm{~cm}$ in $\mathrm{T}_{7}, \mathrm{~T}_{8}$ and $\mathrm{T}_{9}$ respectively and $\mathrm{T}_{10}, \mathrm{~T}_{7}, \mathrm{~T}_{8}, \mathrm{~T}_{9}, \mathrm{~T}_{1}, \mathrm{~T}_{3}$ and $\mathrm{T}_{2}$ were found at par. In 2016-17 maximum finger girth was observed in $\mathrm{T}_{6}(14.98 \mathrm{~cm})$ followed by $\mathrm{T}_{5}(14.77 \mathrm{~cm}), \mathrm{T}_{3}(14.04 \mathrm{~cm})$. There was no statistical difference recorded in between $\mathrm{T}_{6}, \mathrm{~T}_{5}$ and $\mathrm{T}_{4}$. Minimum finger girth of $13.17 \mathrm{~cm}$ was recorded in $\mathrm{T}_{10}$ followed by $13.27 \mathrm{~cm}, 13.48 \mathrm{~cm}, 13.52 \mathrm{~cm}$ in $\mathrm{T}_{7}, \mathrm{~T}_{8}$ and $\mathrm{T}_{9}$ respectively. And there was statistical difference recorded in between $\mathrm{T}_{10}, \mathrm{~T}_{7}, \mathrm{~T}_{8}, \mathrm{~T}_{9}$, $\mathrm{T}_{1}, \mathrm{~T}_{4}$. 
Table.1 Effect of pre harvest treatment of $\mathrm{GA}_{3}$ and $\mathrm{CaCl}_{2}$ on bunch length, bunch girth, bunch weight and number of hands/ bunch of banana cv. Grand Naine

\begin{tabular}{|c|c|c|c|c|c|c|c|c|}
\hline Treatment & \multicolumn{2}{|c|}{$\begin{array}{c}\text { Bunch length } \\
(\mathbf{c m})\end{array}$} & \multicolumn{2}{c|}{$\begin{array}{c}\text { Bunch girth } \\
\mathbf{( c m}\end{array}$} & \multicolumn{2}{c|}{$\begin{array}{c}\text { Bunch weight } \\
\text { (kg) }\end{array}$} & \multicolumn{2}{|c|}{$\begin{array}{c}\text { Number of } \\
\text { hands /bunch }\end{array}$} \\
\cline { 2 - 10 } & $2015-$ & $2016-$ & $2015-$ & $2016-$ & $2015-$ & $2016-$ & $2015-$ & $2016-$ \\
& 16 & 17 & 16 & 17 & 16 & 17 & 16 & 17 \\
\hline $\mathbf{T}_{\mathbf{1}}$ & 81.9 & 84.0 & 99.4 & 99.3 & 22.1 & 18.3 & 9.03 & 8.10 \\
\hline $\mathbf{T}_{\mathbf{2}}$ & 83.7 & 82.1 & 103.8 & 104.2 & 22.6 & 18.8 & 8.77 & 9.45 \\
\hline $\mathbf{T}_{\mathbf{3}}$ & 82.6 & 85.3 & 100.1 & 100.4 & 22.7 & 19.4 & 9.23 & 9.82 \\
\hline $\mathbf{T}_{\mathbf{4}}$ & 83.3 & 81.7 & 105.9 & 107.6 & 24.7 & 22.0 & 8.48 & 9.91 \\
\hline $\mathbf{T}_{\mathbf{5}}$ & 82.4 & 84.3 & 107.6 & 108.7 & 24.9 & 22.8 & 9.15 & 8.83 \\
\hline $\mathbf{T}_{\mathbf{6}}$ & 82.0 & 82.6 & 110.5 & 110.1 & 25.7 & 23.9 & 9.02 & 8.63 \\
\hline $\mathbf{T}_{\mathbf{7}}$ & 84.4 & 82.1 & 96.7 & 97.4 & 22.9 & 20.1 & 8.45 & 8.87 \\
\hline $\mathbf{T}_{\mathbf{8}}$ & 84.1 & 82.2 & 98.1 & 98.1 & 23.1 & 19.7 & 8.90 & 8.64 \\
\hline $\mathbf{T}_{\mathbf{9}}$ & 81.4 & 83.7 & 98.5 & 98.5 & 23.4 & 20.9 & 9.01 & 9.15 \\
\hline $\mathbf{T}_{\mathbf{1 0}}$ & 84.2 & 82.3 & 97.9 & 96.7 & 22.4 & 19.2 & 8.67 & 8.88 \\
\hline $\mathbf{S E}(\mathbf{m}) \mathbf{\pm}$ & 2.93 & 3.07 & 3.04 & 3.23 & 1.65 & 1.54 & 0.402 & 0.419 \\
\hline $\mathbf{C D}(\mathbf{0 . 0 5}$ & - & - & 9.0 & 9.6 & 4.9 & 4.6 & - & - \\
\hline
\end{tabular}

Table.2 Effect of Pre harvest treatment on number of fingers/hand, finger length and finger girth of banana cv. Grand Naine

\begin{tabular}{|c|c|c|c|c|c|c|}
\hline \multirow{2}{*}{ Treatment } & \multicolumn{2}{|c|}{$\begin{array}{c}\text { Number of } \\
\text { fingers/hand }\end{array}$} & \multicolumn{2}{c|}{ Finger length (cm) } & \multicolumn{2}{c|}{ Finger girth(cm) } \\
\cline { 2 - 7 } & $2015-16$ & $2016-17$ & $2015-16$ & $2016-17$ & $2015-16$ & $2016-17$ \\
\hline $\mathbf{T}_{\mathbf{1}}$ & 16.87 & 16.62 & 23.10 & 22.08 & 13.76 & 13.55 \\
\hline $\mathbf{T}_{\mathbf{2}}$ & 16.96 & 16.59 & 23.66 & 22.71 & 13.86 & 13.63 \\
\hline $\mathbf{T}_{\mathbf{3}}$ & 16.53 & 16.07 & 23.45 & 22.78 & 14.06 & 13.77 \\
\hline $\mathbf{T}_{\mathbf{4}}$ & 16.13 & 15.62 & 24.02 & 23.04 & 14.13 & 14.04 \\
\hline $\mathbf{T}_{\mathbf{5}}$ & 16.82 & 16.13 & 24.70 & 23.78 & 14.86 & 14.77 \\
\hline $\mathbf{T}_{\mathbf{6}}$ & 16.50 & 15.81 & 25.87 & 24.83 & 15.10 & 14.98 \\
\hline $\mathbf{T}_{\mathbf{7}}$ & 16.53 & 15.61 & 22.42 & 21.33 & 13.27 & 13.11 \\
\hline $\mathbf{T}_{\mathbf{8}}$ & 16.82 & 16.39 & 22.61 & 21.48 & 13.48 & 13.42 \\
\hline $\mathbf{T}_{\mathbf{9}}$ & 16.08 & 15.97 & 22.76 & 21.74 & 13.52 & 13.46 \\
\hline $\mathbf{T}_{\mathbf{1 0}}$ & 16.52 & 16.27 & 22.32 & 21.33 & 13.17 & 13.11 \\
\hline $\mathbf{S E}(\mathbf{m}) \mathbf{\pm}$ & 0.663 & 0.732 & 0.723 & 0.736 & 0.411 & 0.403 \\
\hline $\mathbf{C D}(\mathbf{0 . 0 5})$ & - & - & 2.13 & 2.17 & 1.21 & 1.20 \\
\hline
\end{tabular}


Table.3 Economics of pre harvest treatment of $\mathrm{GA}_{3}$ and $\mathrm{CaCl}_{2}$ on banana cv. Grand Naine

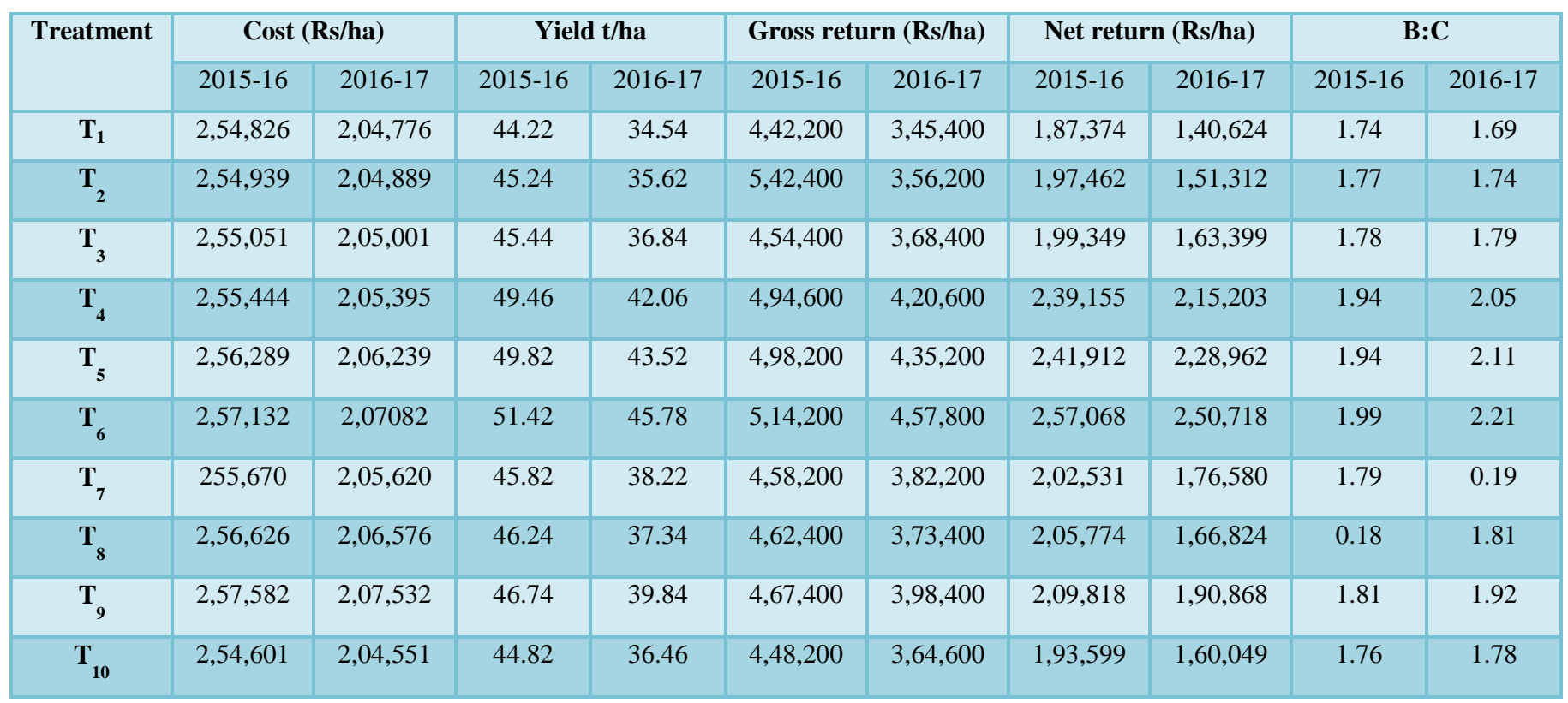

\section{Economics}

It is observed from Table 3 that maximum of 1.99 during 2015-16 and 2.21 during 2016-17 benefit cost ratio was recorded in $\mathrm{T}_{6}$, followed by $\mathrm{T}_{5}$ and $\mathrm{T}_{4}$, with highest yield of $51.42 \mathrm{t} / \mathrm{ha}$ during 2015-16 and 45.78t/ha during 2016-17. Whereas minimum yield 44.82t/ha and 36.46t/ha during 2015-16 and 2016-17 respectively was recorded in control.

It is reveled in experiment, that maximum of benefit cost ratio of 1.99 during 2015-16 and 2.21 during 2016-17 was recorded in $\mathrm{GA}_{3}$ @ 150 ppm followed by $\mathrm{GA}_{3} @ 100$ ppm and $\mathrm{GA}_{3} @ 50 \mathrm{ppm}$, with highest yield of 51.42t/ha during 2015-16 and 45.78t/ha during 2016-17. Whereas minimum yield 44.82t/ha and 36.46t/ha during 2015-16 and 2016-17 respectively was recorded in control.

Due to pre harvest treatment as spraying to bunch were carried out during their developmental stage it gets sufficient time to be absorbed by the fruits and superiority over control observed. GA 3 @150 ppm showed it superiority over others followed by $\mathrm{GA}_{3} @$
$100 \mathrm{ppm}$ but when they applied in combination with $\mathrm{CaCl}_{2}$ there was no superiority recorded it might be due to incompatibility of $\mathrm{GA}_{3}$ and $\mathrm{CaCl}_{2} . \mathrm{GA}_{3}$ accelerate cell division and cell expansion hence fruit weight increased for which yield increased in all $\mathrm{GA}_{3}$ treated plants.

In conclusion, the present experiment entitled Effect of pre harvest treatment of gibberellic acid and calcium chloride on bunch weight of Banana (Musa spp.) cv. Grand Naine conducted during 2015-16 and 2016-17 revealed that Pre harvest spray of $\mathrm{GA}_{3} @ 150$ ppm significantly increased the bunch weight, yield with maximum benefit cost ratio in plant crop and ratoon crop.

\section{References}

NHB Database, Area, Production, Productivity of major fruit crops in India, 2015, www.nhb.gov.in.

Samson JA. 1980. Tropical Fruits, Longman, London and New York. 250p.

Saravanan S, Suchitra V, Rakesh K and Bandral J. 2012. Influence of wax 
coating and indigenous potassium permanganate based ethylene absorbents on shelf life of banana cv. Dwarf Cavendish, International Journal of Processing and Post-Harvest Technology, 3: 129-133.

Singh J. 2002. Basic Horticulture, Kalyani
Publication Ludhiana. pp. 6. Wills RBH, McGlasson WB, Gratam D, Lee TH and Hall EG. 1981. Post harvest an introductions to the physiology and handling of fruit and vegetable, CBS publications and distributions, Daryaganja, New Delhi: 17.

\section{How to cite this article:}

Lipsa Prit Bhusan, D.K. Dash and Das, A.K. 2020. Effect of Pre Harvest Treatment of Gibberellic Acid and Calcium Chloride on Bunch Weight of Banana (Musa spp.) cv. Grand Naine. Int.J.Curr.Microbiol.App.Sci. 9(12): 1776-1781.

doi: https://doi.org/10.20546/ijcmas.2020.912.210 